MINERALOGIA, 39, No. 1-2: 53-65 (2008)

DOI: $10.2478 / v 10002-008-0004-6$

www.Mineralogia.pl

MINERALOGICAL SOCIETY OF POLAND

Original paper

\title{
Genesis and stability of accessory phosphates in silicic magmatic rocks: a Western Carpathian case study
}

\author{
Igor BROSKA ${ }^{*}$, Igor PETRÍK ${ }^{1}$ \\ 1 Geological Institute, Slovak Academy of Sciences, Dúbravská cesta 9, 84005 Bratislava, Slovak Republic, \\ e-mail: igor.broska@savba.sk \\ * Corresponding author
}

Received: December 12, 2007

Accepted: April 30, 2008

\begin{abstract}
The formation of accessory phosphates in granites reflects many chemical and physical factors, including magma composition, oxidation state, concentrations of volatiles and degree of differentiation. The geotectonic setting of granites can be judged from the distribution and character of their phosphates. Robust apatite crystallization is typical of the early magmatic crystallization of I-type granitoids, and of late magmatic stages when increased Ca activity may occur due to the release of anorthite from plagioclase. Although S-type granites also accumulate apatite in the early stages, increasing phosphorus in late differentiates is common due to their high ASI. The apatite from the S-types is enriched in Mn compared to that in I-type granites. A-type granites characteristically contain minor amounts of apatite due to low P concentrations in their magmas. Monazite is typical of S-type granites but it can also become stable in late I-type differentiates. Huttonite contents in monazite correlate roughly positively with temperature. The cheralite molecule seems to be highest in monazite from the most evolved granites enriched in B and F. Magmatic xenotime is common mainly in the S-type granites, but crystallization of secondary xenotime is not uncommon. The formation of the berlinite molecule in feldspars in peraluminous melts may suppress phosphate precipitation and lead to distributional inhomogeneities. Phosphate mobility commonly leads to the formation of phosphate veinlets in and outside granite bodies. The stability of phosphates in the superimposed, metamorphic processes is restricted. Both monazite-(Ce) and xenotime-(Y) are unstable during fluid-activated overprinting. REE accessories, especially monazite and allanite, show complex replacement patterns culminating in late allanite and epidote formation.
\end{abstract}

Key-words: phosphates, monazite, apatite, xenotime, granite, Western Carpathians

\section{Introduction}

The distribution and character of the phosphates apatite, monazite and xenotime are important in the discrimination of granitic rocks. In the West-Carpathian Variscan basement, 
the contents and compositional characteristics of accessory phosphates discriminate between I-, S-, A- and specialized S-type granites.

The Variscan plutonic (mostly granitic) rocks of Western Carpathians form major part of the pre-Alpine basement involved in the Alpine large-scale stack of thrust slices (cf. Plašienka et al. 1997). They occur in all three main south-dipping Alpine superunits ( $\mathrm{N}$ to S): Tatric, Veporic and Gemeric. The granitoids $s$. $l$. can be divided into several suites originated during orogenic to post-orogenic stages dated back in relation to the main Upper-Devonian/Lower Carboniferous Variscan collision and Middle/Upper Carboniferous post-collisional phases.

Each granitoid suite is composed of several types of granitic rocks, geochemically and mineralogically reflecting the character of the source rock and physico-chemical condititions of home geotectonic environments. In the Lower Carboniferous (Meso-Variscan stage) S- and I-type orogenic suites has been defined with dominancy of S-type, in the Middle-Upper Carboniferous period (Neo-Variscan stage) I- and I/S-type granites dominate. Post-orogenic granite suites involve the Permian A-type granite and F and B specialized S-type granites (Fig. 1).

The distribution of monazite is controlled by magma REE behaviour and, as in the case of apatite, by $\mathrm{P}$ chemistry. Monazite contents in granites are very variable. Monazite is typical of S-type granitic rocks, but is usually absent in I-types with exception of late differentiates. Monazite is also rare or absent in F, B specialized S-type granites. Apatite concentrations are variable but generally higher in cumulate-rich tonalites and in some peraluminous leucogranites.

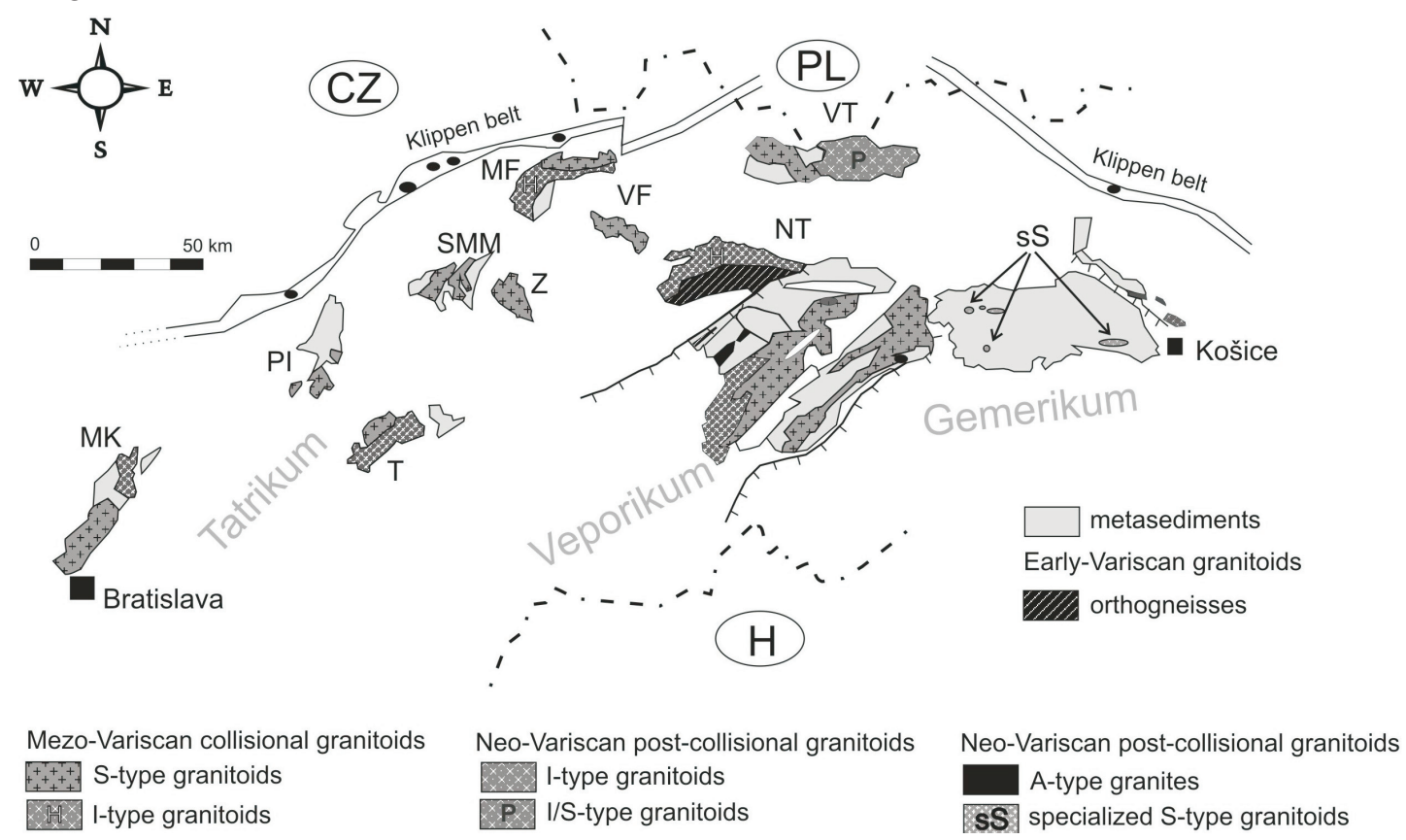

Fig. 1. Position of Variscan granitoids in the Western Carpathians

Mountains abbreviations: MK - Malé Karpaty, PI - Považský Inovec, T - Tribeč, SMM- Suchý a Malá Magura, MF - Malá Fatra, VF -Vel'ká Fatra, NT - Nízke Tatry, VT -Vysoké Tatry, sS - specialised S-type granites 
In this work, the occurrence and character of the dominant phosphate accessories is used to aid understanding of magmatic evolution. The results of research over the last decades on the role of accessory phosphates in Western Carpathian granitic rocks are reviewed.

\section{Phosphate accessory phases in granitic rocks}

\subsection{Apatite}

Apatite shows hexagonal structure $P 6_{3} / m$, although synthetic chlorapatite and hydroxylapatite is known also in monoclinic space group $P 2_{1} / b$ (Hughes and Rakovan 2002). Apatite is remarkably tolerant to structural distortion and chemical substitution, and can be described by the general formula $\mathrm{A}_{5}\left(\mathrm{XO}_{4}\right)_{3} \mathrm{Z}$. Many cations, e.g., $\mathrm{K}, \mathrm{Na}, \mathrm{Ba}, \mathrm{Sr}, \mathrm{Mn}, \mathrm{Fe}, \mathrm{Y}$, REEs and $\mathrm{U}$ can substitute for $\mathrm{Ca}$ and anionic complexes such as $\mathrm{SO}_{4}{ }^{2-}, \mathrm{SiO}_{4}{ }^{4-}, \mathrm{CO}_{3}{ }^{2-}$ can replace $\mathrm{PO}_{4}{ }^{3-}$ (Hughes and Rakovan 2002; Pan and Fleet 2002). Apatite is a very important concentrator of REEs in igneous rocks (Nash 1972; Watson and Capobianco 1981; Gromet and Silver 1983; Watson and Harrison 1984). The term apatite encompasses the three end-member minerals apatite-(CaF) $\mathrm{Ca}_{5}\left(\mathrm{PO}_{4}\right)_{3} \mathrm{~F}$, apatite- $(\mathrm{CaCl}) \mathrm{Ca}_{5}\left(\mathrm{PO}_{4}\right)_{3} \mathrm{Cl}$ and apatite- $(\mathrm{CaOH}) \mathrm{Ca}_{5}\left(\mathrm{PO}_{4}\right)_{3}(\mathrm{OH})$. The isomorphous carbonate-apatite $\mathrm{Ca}_{5}\left(\mathrm{PO}_{4}\right)_{3-\mathrm{x}}\left(\mathrm{CO}_{3} \mathrm{~F}_{\mathrm{x}}\right)(\mathrm{F}, \mathrm{OH}, \mathrm{Cl})$ end-member is less common.

Apatite is typical of the granite environment. The key compositional criteria bearing on the recognition of I-, S- and A-type granitoids are the concentrations of $\mathrm{Mn}$ and Fe in the A (Ca) site, along with REE distribution (Table 1). The Mn content in apatite from the Western Carpathians increases with peraluminosity and with decreasing $f \mathrm{O}_{2}$. Thus, because divalent $\mathrm{Mn}$ easily substitutes for $\mathrm{Ca}$, apatite from S-type granites has slightly higher Mn contents in comparison to apatite from I-types. In addition, the anionic complex $\mathrm{SO}_{3}{ }^{2-}$ characterises apatite from the latter. Apatite from A-type granites is enriched in Fe and HREE. Apatites from specialized Sn-bearing S-type granitoids also show increased $Y$ and HREE (Broska et al. 2004). Apatite-(CaSrF) from the Li-F specialized granite porphyry occurring in the Gemeric unit (Fig. 1) may contain extremely high $\mathrm{Sr}(>9 \% \mathrm{SrO})$ and $\mathrm{Mn}(>5 \% \mathrm{MnO})$ due to the absence of biotite and $\mathrm{Ca}$ plagioclase. The distribution of $\mathrm{Mn}$ and $\mathrm{Fe}$ in the different granites is generalised in Fig. $2 \mathrm{~A}$ and that of $\mathrm{S}$ and REE in Fig. 2B. In addition to minor femic and REE components, volatiles phases are also important discriminants in apatite. Although $\mathrm{F}$ and $\mathrm{Cl}$ contents are similar in all granitoids of the Western Carpathians, apatite chlorine contents are usually slightly higher in I-type rocks. The highest contents of the apatite molecule characterise the topaz-bearing S-type granites. $\mathrm{Cl}$ depletion in apatite from S-type granites has been ascribed to its earlier loss during weathering processes.

In addition to primary apatite, a distinct secondary type occurs as a leaching product of the berlinite molecule in the alkali feldspars. Berlinite, $\mathrm{AlPO}_{4}$, is isostructural with quartz or the $\mathrm{Si}_{2} \mathrm{O}_{4}$ framework component of feldspars and is incorporated into feldspars by the coupled substitution of $\mathrm{Al}^{3+}+\mathrm{P}^{5+}$ for $2 \mathrm{Si}^{4+}$. This exchange is the well-known berlinite substitution (London 1992; 1998). Postmagmatic fluids release P from the berlinite molecule and Ca from the anorthite molecule and secondary apatite are precipitated (Fig. 3A). This apatite is seen as minute crystals of near-stoichiometric composition (Table 1) usually within albite, but occasionally within K-feldspar. Mass balance calculation shows that the secondary apatite in 
albite could be derived from oligoclase with An content $<20$ (Broska et al. 2002). As P mobility in postmagmatic fluids is high, secondary apatite may occur not only as minute crystals in feldspar but in veinlets (Fig. 3B) - even in veins cutting granite roof rocks (Fig. 3C, D).

TABLE 1

Representative compositions of apatites- $(\mathrm{CaF}) \mathrm{s}$ in selected I and S-type granites, Western Carpathians

\begin{tabular}{|c|c|c|c|c|c|}
\hline $\begin{array}{l}\text { Granite } \\
\text { type } \\
\text { sample }\end{array}$ & $\begin{array}{l}\text { S-type } \\
\text { primary } \\
\text { BGS-8 }\end{array}$ & $\begin{array}{l}\text { S-type } \\
\text { primary } \\
\text { BGS-8 }\end{array}$ & $\begin{array}{c}\text { Spec. S-type } \\
\text { secondary } \\
\text { GK-8 }\end{array}$ & $\begin{array}{l}\text { I-type } \\
\text { primary } \\
\text { ZK-38 }\end{array}$ & $\begin{array}{l}\text { I-type } \\
\text { primary } \\
\text { ZK-38 }\end{array}$ \\
\hline $\mathrm{SO}_{3}$ & 0.03 & 0.01 & 41.8 & 0.07 & 0.10 \\
\hline $\mathrm{P}_{2} \mathrm{O}_{5}$ & 41.98 & 42.16 & 0.07 & 41.95 & 42.48 \\
\hline $\mathrm{SiO}_{2}$ & 0.03 & 0.04 & 55.27 & 0.14 & 0.04 \\
\hline $\mathrm{CaO}$ & 54.39 & 54.38 & 0.00 & 54.83 & 54.64 \\
\hline $\mathrm{La}_{2} \mathrm{O}_{3}$ & 0.06 & 0.02 & 0.10 & 0.04 & 0.02 \\
\hline $\mathrm{Ce}_{2} \mathrm{O}_{3}$ & 0.09 & 0.04 & 0.03 & 0.02 & 0.02 \\
\hline $\mathrm{Pr}_{2} \mathrm{O}_{3}$ & 0.01 & 0.07 & 0.03 & 0.04 & 0.01 \\
\hline $\mathrm{Nd}_{2} \mathrm{O}_{3}$ & 0.06 & 0.19 & 0.06 & 0.12 & 0.01 \\
\hline $\mathrm{Sm}_{2} \mathrm{O}_{3}$ & 0.07 & 0.04 & 0.00 & 0.09 & 0.00 \\
\hline $\mathrm{Gd}_{2} \mathrm{O}_{3}$ & 0.02 & 0.03 & 0.00 & 0.01 & 0.00 \\
\hline $\mathrm{Er}_{2} \mathrm{O}_{3}$ & 0.00 & 0.02 & 0.00 & 0.01 & 0.01 \\
\hline $\mathrm{Dy}_{2} \mathrm{O}_{3}$ & 0.01 & 0.01 & 0.00 & 0.01 & 0.00 \\
\hline $\mathrm{Yb}_{2} \mathrm{O}_{3}$ & 0.00 & 0.00 & 0.03 & 0.00 & 0.00 \\
\hline $\mathrm{Y}_{2} \mathrm{O}_{3}$ & 0.29 & 0.19 & 0.00 & 0.11 & 0.02 \\
\hline $\mathrm{ThO}_{2}$ & 0.01 & 0.08 & 0.05 & 0.02 & 0.00 \\
\hline $\mathrm{UO}_{2}$ & 0.10 & 0.02 & 0.00 & 0.10 & 0.06 \\
\hline $\mathrm{Al}_{2} \mathrm{O}_{3}$ & 0.02 & 0.04 & 0.00 & 0.02 & 0.00 \\
\hline $\mathrm{FeO}$ & 0.31 & 0.27 & 0.00 & 0.05 & 0.05 \\
\hline $\mathrm{MnO}$ & 0.33 & 0.29 & 0.00 & 0.07 & 0.13 \\
\hline $\mathrm{MgO}$ & 0.07 & 0.06 & 0.00 & 0.00 & 0.01 \\
\hline $\mathrm{Na}_{2} \mathrm{O}$ & 0.14 & 0.09 & 0.05 & 0.08 & 0.12 \\
\hline $\mathrm{SrO}$ & 0.07 & 0.06 & 0.01 & 0.12 & 0.10 \\
\hline $\mathrm{F}$ & 2.37 & 2.51 & 3.20 & 2.19 & 1.96 \\
\hline $\mathrm{Cl}$ & 0.03 & 0.04 & 0.00 & 0.05 & 0.06 \\
\hline $\mathrm{OH}$ & 0.56 & 0.50 & 0.22 & 0.63 & 0.72 \\
\hline total & 101.05 & 101.15 & 100.92 & 100.76 & 100.56 \\
\hline $\mathrm{O}=\mathrm{F}, \mathrm{Cl}$ & 1.00 & 1.07 & 1.35 & 0.93 & 0.84 \\
\hline TOTAL & 100.05 & 100.08 & 99.57 & 99.82 & 99.72 \\
\hline $\mathrm{X}_{\mathrm{Ap}} \mathrm{Fp}$ & 0.639 & 0.676 & 0.859 & 0.591 & 0.530 \\
\hline $\mathrm{X}^{\mathrm{Ap}} \mathrm{ClAp}_{\mathrm{Al}}$ & 0.004 & 0.006 & 0.000 & 0.008 & 0.009 \\
\hline $\mathrm{X}_{\mathrm{HAp}}^{\mathrm{Ap}}$ & 0.357 & 0.318 & 0.141 & 0.401 & 0.461 \\
\hline
\end{tabular}



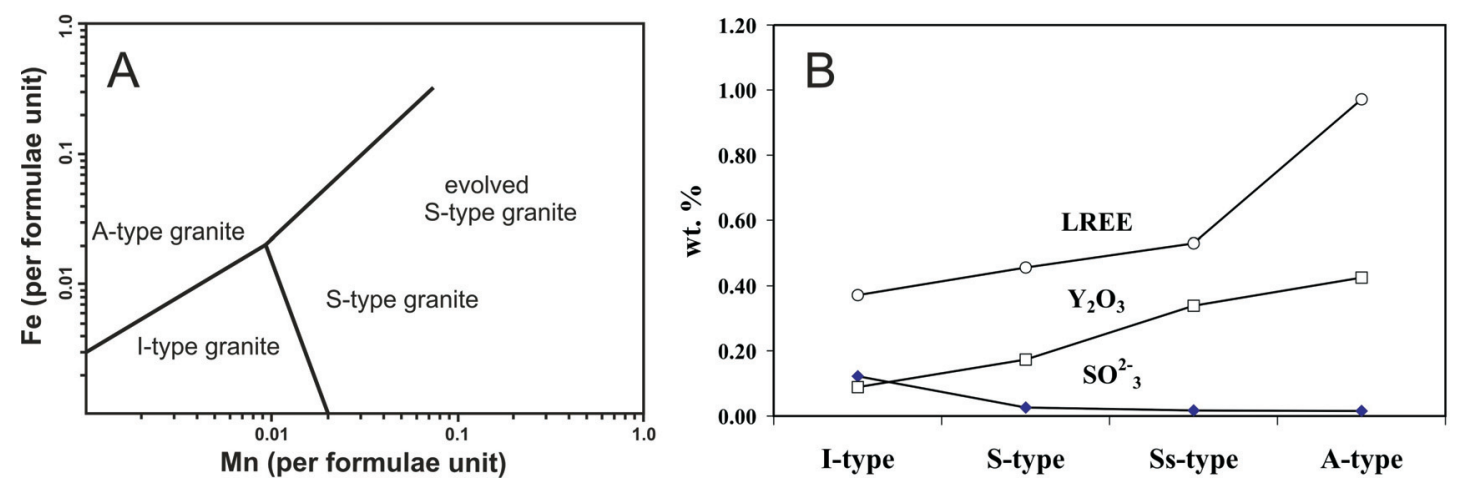

Fig. 2. Compositional variability in apatites-(CaF) form the I-, S-, A- and specialised S-type granitoids A - Discriminative Mn and Fe character in apatite. The highest Mn content characterises evolved specialized S-type granites (after Broska et al. 2005); B - Mean S and REE concentrations in apatites-(CaF)
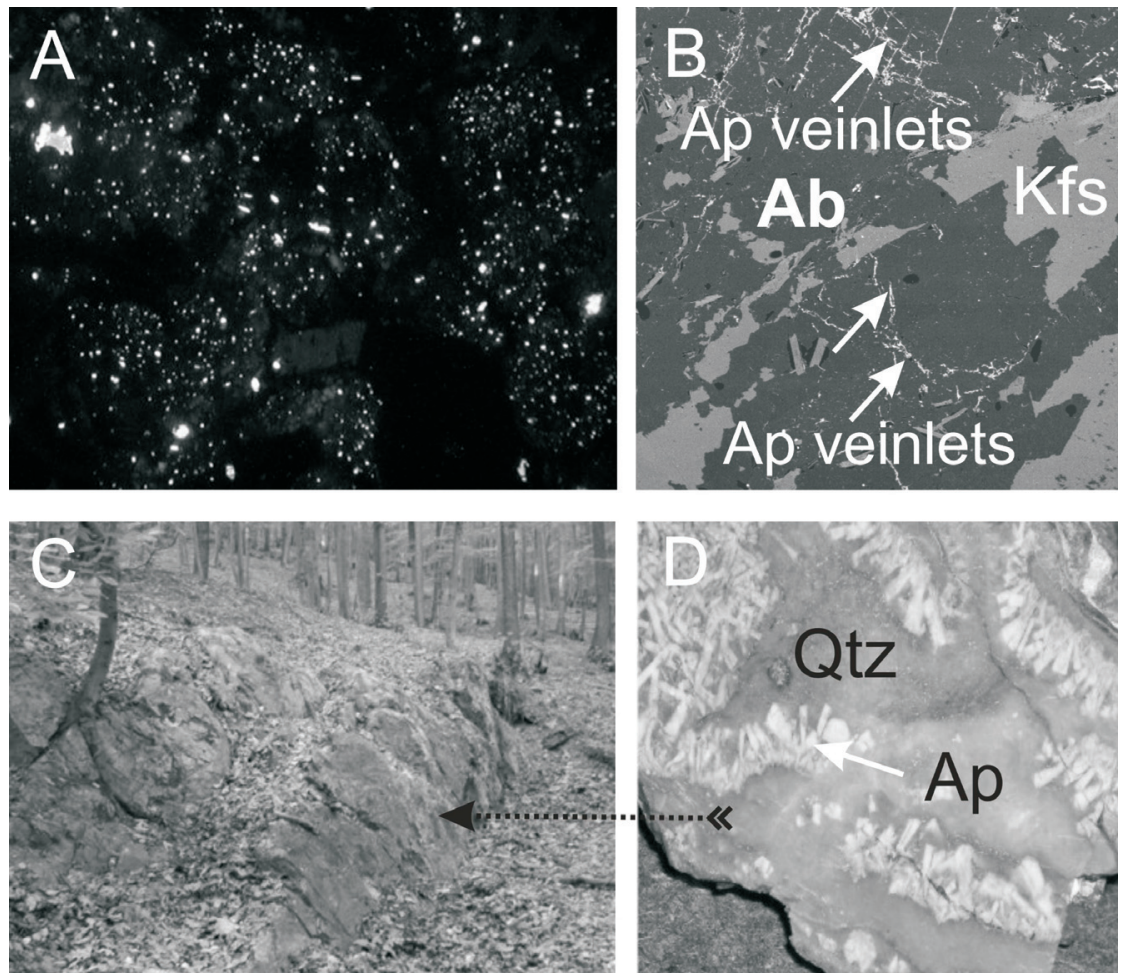

Fig. 3. Textural character of apatite from specialised S-type granites

A - CL image of secondary apatite distribution in plagioclases in granites from Spiš-Gemer (sample GK-9) Light dots represent the apatite. Boundaries of feldspar grains are still visible (mang. approx. 60×);

B - Veinlets of apatite in the evolved granitic system in the Western Carpathians (Dlhá dolina valley) (mang. approx. 60×); C, D - locality of dike and texture of quartz-apatite dike enriched by REE, Th and U phases. Apatite $0.5-1 \mathrm{~cm}$ stuby crystals in quartz matrix. Locality Čučma (artificial trench) 


\subsection{Monazite-(Ce)}

The monazite structure refined by $\mathrm{Ni}$ et al. (1995) belongs to space group P21/n. It is composed of chains parallel to the c-axis with alternating $\mathrm{PO}_{4}$ tetrahedra incorporating larger ions (REE, $\mathrm{Ca}, \mathrm{Th}, \mathrm{U}$ ). The monazite structure accepts larger REE from La-Tb. The actinides Th and $\mathrm{U}$ enter monazite through two known substitutions - a huttonite-like substitution $\mathrm{Th}^{4+}+\mathrm{Si}^{4+}=\mathrm{RE}^{3+}+\mathrm{P}^{5+}$ and a cheralite-like substitution $\mathrm{Th}^{4+}+\mathrm{Ca}^{2+}=2 \mathrm{RE}^{3+}$ (Cuney and Friedrich 1987; Burt 1989; Förster 1998a; Fig. 4).

Natural monazite, containing isostructural molecules of huttonite $\left[\mathrm{ThSiO}_{4}\right]$ and cheralite $\left[\mathrm{CaTh}\left(\mathrm{PO}_{4}\right)_{2}\right]$, can be theoretically deemed a multicomponent system. It is a solid solution of the 14 rare earth phosphates $\mathrm{REEPO}_{4}$, the huttonite or $\mathrm{U}$ - and Th-silicates $\left(\mathrm{USiO}_{4}, \mathrm{ThSiO}_{4}\right)$, two brabantite-like end-members $\left(\mathrm{CaTh}\left(\mathrm{PO}_{4}\right)_{2}, \mathrm{CaU}\left(\mathrm{PO}_{4}\right)_{2}\right)$ and the molecules $\mathrm{YPO}_{4}, \mathrm{USiO}_{4}$ and $\mathrm{YPO}_{4}$ which, though not known to be monoclinic, must be defined as virtual end-members to complete the chemical composition of natural monazite (Bowie and Horne 1953; Kucha 1980; Burt 1989; Hughes et al. 1995; Pyle et al. 2001. Locally, gasparite $\left(\mathrm{LREEAsO}_{4}\right)$ and "clinoanhydrite" $\left(\mathrm{CaSO}_{4}\right)$ molecules may be important in monazite - as in Tisovec, Slovakia (Ondrejka et al. 2007).

Brabantite is an alternative name for the end member $\left[\mathrm{CaTh}\left(\mathrm{PO}_{4}\right)_{2}\right]$. It was first named by Rose (1980) after Brabant in Namibia. This term, synonymous with cheralite (Bowie and Horne 1953) should be abandoned as the name cheralite has been in use earlier (Linthout 2007).

Table 2 presents representative chemical compositions of monazite-(Ce) for both the $\mathrm{S}$ - and I-type granites. The average concentrations of some of the most important elements differ in comparable granite suites. Monazites in S-type granite show lower contents of the cheralite component compared to those in the most evolved specialized S-type granite (Table 2). The cheralite component in monazites from S-type granites is usually $<10 \mathrm{~mol} \%$. In contrast, highly evolved granites in the Dlhá Dolina valley (Slovenské Rudohorie Mts.) commonly contain monazites with $>20-30 \mathrm{~mol} \%$ cheralite. Higher temperatures seem to favour greater huttonite incorporation in monazites (Broska et al. 2000). Besides huttonite and cheralite, xenotime contents in monazite may reach considerable proportions. Petrík et al. (2006) report monazite coexisting with xenotime in orthogneiss as containing 2-7 mol\% xenotime.

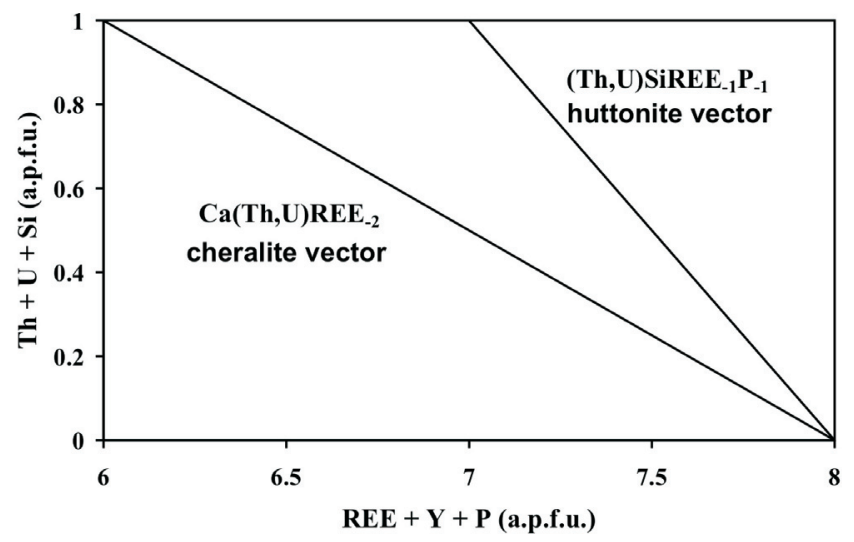

Fig. 4. Monazite compositional vectors showing dominant huttonite and cheralite substitutions 
TABLE 2

Representative compositions of monazite and xenotime from main granitoid types, Western Carpathians

\begin{tabular}{|c|c|c|c|c|c|c|c|c|c|c|}
\hline $\begin{array}{c}\text { Sample } \\
\text { point } \\
\text { granite } \\
\text { mineral }\end{array}$ & $\begin{array}{c}\text { GK-8 } \\
\text { core } \\
\text { s.S-type } \\
\text { mnz }\end{array}$ & $\begin{array}{c}\text { GK-8 } \\
\text { core } \\
\text { s.S-type } \\
\text { mnz }\end{array}$ & $\begin{array}{c}\text { DD-908 } \\
\text { core } 3-3 \\
\text { s.S-type } \\
\text { mnz }\end{array}$ & $\begin{array}{c}\text { BGS-8 } \\
\text { core } \\
\text { S-type } \\
\text { mnz }\end{array}$ & $\begin{array}{c}\text { BGS-8 } \\
\text { core } \\
\text { S-type } \\
\text { mnz }\end{array}$ & $\begin{array}{c}\text { PI-25 } \\
\text { core1 } \\
\text { S-type } \\
\text { xnt }\end{array}$ & $\begin{array}{c}\text { PI-25 } \\
\text { rim1 } \\
\text { S-type } \\
\text { xnt }\end{array}$ & $\begin{array}{c}\text { BP-20 } \\
\text { core } \\
\text { A-type } \\
\text { mnz }\end{array}$ & $\begin{array}{c}\text { VG-87 } \\
\text { core } \\
\text { A-type } \\
\text { mnz }\end{array}$ & $\begin{array}{c}\text { VG-87 } \\
\text { rim } \\
\text { A-type } \\
\text { mnz }\end{array}$ \\
\hline $\mathrm{SiO}_{2}$ & 1.27 & 0.77 & 0.40 & 0.25 & 0.21 & 0.51 & 0.33 & 1.45 & 0.82 & 0.60 \\
\hline $\mathrm{P}_{2} \mathrm{O}_{5}$ & 28.01 & 28.57 & 29.92 & 30.83 & 30.57 & 33.22 & 33.64 & 28.84 & 27.87 & 29.13 \\
\hline $\mathrm{CaO}$ & 1.64 & 1.64 & 2.53 & 0.92 & 1.22 & 0.14 & 0.09 & 3.04 & 0.75 & 0.62 \\
\hline $\mathrm{Y}_{2} \mathrm{O}_{3}$ & 0.83 & 0.58 & 2.73 & 2.36 & 1.77 & 41.07 & 42.41 & 1.09 & 1.18 & 2.30 \\
\hline $\mathrm{La}_{2} \mathrm{O}_{3}$ & 7.88 & 7.46 & 7.84 & 12.79 & 14.16 & 0.07 & 0.00 & 9.66 & 16.53 & 14.65 \\
\hline $\mathrm{Ce}_{2} \mathrm{O}_{3}$ & 25.55 & 25.24 & 21.95 & 27.06 & 28.23 & 0.16 & 0.01 & 24.33 & 28.77 & 27.91 \\
\hline $\mathrm{Pr}_{2} \mathrm{O}_{3}$ & 3.32 & 3.38 & 2.70 & 3.27 & 2.91 & 0.00 & 0.07 & 3.05 & n.d. & n.d. \\
\hline $\mathrm{Nd}_{2} \mathrm{O}_{3}$ & 11.25 & 13.05 & 9.73 & 11.32 & 10.23 & 0.29 & 0.34 & 12.05 & 14.97 & 15.40 \\
\hline $\mathrm{Sm}_{2} \mathrm{O}_{3}$ & 4.29 & 4.72 & 2.51 & 2.46 & 1.93 & 0.55 & 0.51 & 2.34 & 1.97 & 2.88 \\
\hline $\mathrm{Gd}_{2} \mathrm{O}_{3}$ & 2.51 & 2.68 & 3.12 & 1.86 & 1.55 & 2.16 & 1.96 & 1.20 & 0.36 & 1.87 \\
\hline $\mathrm{Dy}_{2} \mathrm{O}_{3}$ & 0.63 & 0.33 & 0.89 & 0.74 & 0.56 & 5.12 & 5.47 & 0.48 & n.d. & n.d. \\
\hline $\mathrm{Er}_{2} \mathrm{O}_{3}$ & 0.00 & 0.00 & 0.29 & 0.05 & 0.06 & 4.41 & 3.93 & 0.04 & 0.22 & 0.00 \\
\hline $\mathrm{Yb}_{2} \mathrm{O}_{3}$ & 0.00 & 0.00 & 0.08 & 0.07 & 0.00 & 4.09 & 3.85 & 0.00 & 0.00 & 0.11 \\
\hline $\mathrm{ThO}_{2}$ & 11.26 & 9.54 & 12.21 & 3.97 & 5.10 & 0.42 & 0.39 & 5.96 & 6.16 & 5.64 \\
\hline $\mathrm{UO}_{2}$ & 0.25 & 0.00 & 1.23 & 0.66 & 0.73 & 2.66 & 1.06 & 0.01 & 0.30 & 0.23 \\
\hline $\mathrm{Al}_{2} \mathrm{O}_{3}$ & 0.02 & 0.03 & 0.00 & 0.01 & 0.00 & 0.00 & 0.00 & 0.53 & n.d. & n.d. \\
\hline $\mathrm{MnO}$ & 0.00 & 0.12 & 0.04 & 0.08 & 0.02 & 0.04 & 0.07 & 0.11 & n.d. & n.d. \\
\hline $\mathrm{FeO}$ & 0.00 & 0.00 & 0.43 & 0.00 & 0.00 & 0.00 & 0.00 & 3.35 & n.d. & n.d. \\
\hline $\mathrm{SrO}$ & 0.00 & 0.19 & 0.00 & 0.07 & 0.11 & 0.00 & 0.00 & 1.21 & n.d. & n.d. \\
\hline $\mathrm{PbO}$ & 0.00 & 0.00 & 0.22 & 0.00 & 0.00 & 0.30 & 0.31 & n.d. & n.d. & n.d. \\
\hline $\mathrm{F}$ & b.d. & 0.00 & 0.79 & 0.13 & 0.13 & b.d. & b.d. & 0.07 & n.d. & n.d. \\
\hline $\mathrm{Cl}$ & b.d. & 0.02 & 0.03 & 0.04 & 0.04 & b.d. & b.d. & 0.03 & n.d. & n.d. \\
\hline total & 98.71 & 98.33 & 99.64 & 98.92 & 99.52 & 95.22 & 94.43 & 98.87 & 99.90 & 101.34 \\
\hline $\mathrm{O}=\mathrm{F}, \mathrm{Cl}$ & 0.00 & 0.00 & 0.34 & 0.07 & 0.06 & 0.00 & 0.00 & 0.03 & 0.00 & 0.00 \\
\hline TOTAL & 98.71 & 98.33 & 99.30 & 98.85 & 99.46 & 95.22 & 94.43 & 98.83 & 99.90 & 101.34 \\
\hline $\mathrm{X}_{\text {LREE }}$ & 0.764 & 0.789 & 0.647 & 0.832 & 0.830 & 0.013 & 0.011 & 0.764 & 0.880 & 0.851 \\
\hline $\mathrm{X}_{\text {HREE }}$ & 0.042 & 0.040 & 0.060 & 0.036 & 0.028 & 0.178 & 0.171 & 0.023 & 0.007 & 0.025 \\
\hline $\mathrm{X}_{\mathrm{YPO} 4}$ & 0.018 & 0.012 & 0.058 & 0.050 & 0.037 & 0.776 & 0.800 & 0.024 & 0.024 & 0.047 \\
\hline Xcher & 0.142 & 0.142 & 0.216 & 0.079 & 0.104 & 0.011 & 0.007 & 0.266 & 0.062 & 0.051 \\
\hline$X_{\text {hut }}$ & 0.035 & 0.017 & 0.016 & 0.003 & 0.001 & 0.022 & 0.011 & -0.078 & 0.026 & 0.026 \\
\hline
\end{tabular}

Note: GK-8 - Hnilec; DD-908 Dlhá dolina; BGS-8 Suchý; PI-25 Považský Inovec; BP-20 Klippen belt (hypersolvus granite); VG-87 Hrončok granite, Vepor (subsolvus granite). 
Monazite in the A-type hypersolvus granites is rare. Subsolvus A-type granites occurring in the Vepor unit (the Hrončok type granite) contain up to 5-7 mol\% of cheralite molecule and relatively low xenotime and huttonite molecules (2-5 and 3 mol\%, respectively). Elevated Fe and $\mathrm{Sr}$ contents were observed in these monazites (Table 2).

\subsection{Xenotime-(Y)}

Whereas monazite is monoclinic, xenotime is tetragonal and isostructural with zircon, i.e., I $4{ }_{1} /$ amd ( $\mathrm{Ni}$ et al. 1995). The structures of both minerals have equal numbers of $\mathrm{PO}_{4}$ tetrahedra and $\mathrm{REO}_{9}$ polyhedra. In xenotime, the polyhedra have a more regular arrangement which accommodates the smaller, heavy REEs more readily (Ni et al. 1995).

In many Western Carpathian granites, xenotime-(Y) grains are compositionally zoned with a slight core-to-rim increase in $\mathrm{Y}$ and decrease in $\mathrm{Th}+\mathrm{U}$. The mole fraction of $\mathrm{YPO}_{4}$ in S-type granitic rocks ranges from $0.84-0.75$ with an average of 0.78 . As with monazite, the coffinite and cheralite substitutions are characteristic (Fig. 5). The heavy REE, principally Gd, Dy, Er and $\mathrm{Yb}$, reach a mole fraction of $0.1-0.2 \mathrm{~mol} \%$. In contrast, the light REE (La-Sm), not readily incorporated into the xenotime structure, attain an average mole fraction of only $4 \mathrm{~mol} \%$. The actinide elements, Th and $\mathrm{U}$, vary in concentration with $\mathrm{U}$ always enriched relative to Th (Table 2).
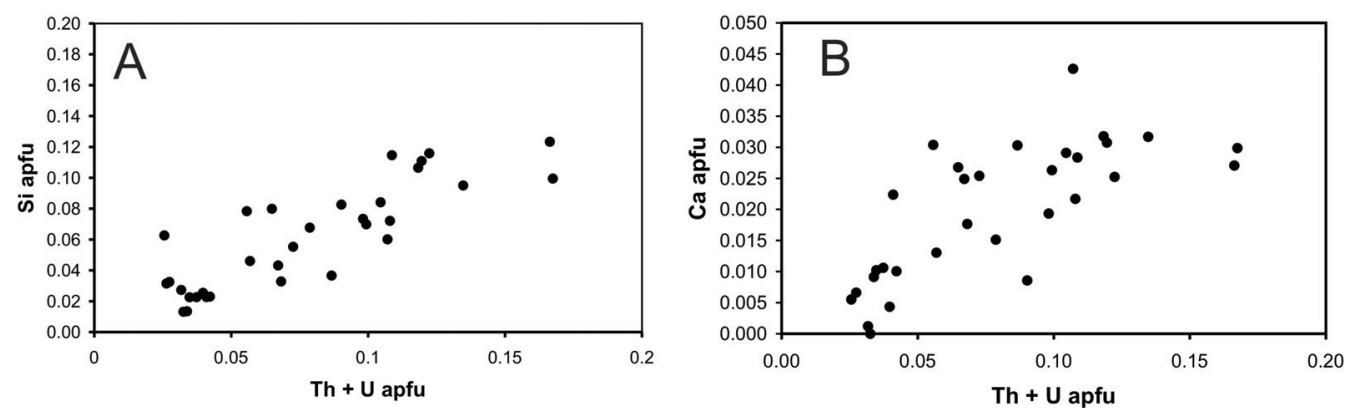

Fig. 5. Xenotime compositions plotted to show coffinite and cheralite exchange relations

Some xenotime-(Y) crystals have a complex zoning pattern suggesting crystallisation from a melt and display a distinctive euhedral core. In general, Th, U, Si and Ca contents decrease from core to rim (Table 2), and $\mathrm{Y}$ and HREE increase. A positive correlation between $(\mathrm{U}+\mathrm{Th}+\mathrm{Si})$ and $(\mathrm{REE}+\mathrm{P})$ in atoms per formula unit indicates coupled substitution corresponding to $(\mathrm{U}+\mathrm{Th}) \mathrm{SiREE}_{-1} \mathrm{P}_{-1}$. The thorite or coffinite component in the xenotime is analogous to the huttonite component in monazite solid solutions (Spear and Pyle 2002). The positive correlation between $(\mathrm{U}+\mathrm{Th}+\mathrm{Ca})$ and $2 \mathrm{REE}$ in xenotime indicates the presence of a cheralite-like molecule - a constituent typical of monazite (Förster 1998a, b; Spear and Pyle 2002).

Evidence for the magmatic origin of xenotime in granites from the Považský Inovec Mts and in the Veporic unit has been presented by Broska et al. (2005). The Nízke Tatry orthogneisses are also saturated with xenotime indicating the role of HREE in their magmatic protolith. Monazite 
and xenotime coexisting in equilibrium give a temperature of $<650^{\circ} \mathrm{C}$ (Broska et al. 2005; Petrík et al. 2006) using the monazite-xenotime thermometer of Heinrich et al. (1997). Most of xenotime is considered to be of late magmatic origin - as has also been proposed, for example, for xenotime in peraluminous granites of the Erzgebirge (Förster 1998b).

Partial replacement of igneous zircon followed by post-magmatic re-crystallization resulted in the production of low-Y zircon and secondary xenotime. This progression from $(\mathrm{Zr}, \mathrm{Hf}, \mathrm{Y}, \mathrm{REE})(\mathrm{Si}, \mathrm{P}) \mathrm{O}_{4}$ (igneous zircon) to $(\mathrm{Zr}, \mathrm{Hf}) \mathrm{SiO}_{4}$ (metamorphic zircon) $+(\mathrm{Y}, \mathrm{REE}) \mathrm{PO}_{4}$ (xenotime) has been formerly described by Pan (1997) from an amphibolite-facies metamorphic overprint. A similar origin for xenotime is known from the S-type granites of the Gemeric unit in the Dlhá dolina valley (Western Carpathians) which are enriched in volatiles such as B, F, LIL and HFSE elements (Rb, Nb, Ta, W) and from the Tatra Mts (Michalik et al. 2000). In both instances, close zircon-xenotime association and mutual overgrowth are evident. New xenotime was probably also precipitated following the leaching of $\mathrm{P}$ and $\mathrm{Y}$ from apatite which contains ca $2 \mathrm{wt} \% \mathrm{Y}_{2} \mathrm{O}_{3}$ (Broska et al. 2004). Similar leaching effects have been described in experimental systems by Harlov and Forster (2003).

\section{General discussion of phosphate distribution in granitic systems}

\subsection{I-type granites}

Apatite is very abundant in early magmatic granite differentiates of I-type affinity; locally it may be a rock-forming mineral. Monazite-(Ce) is present only in late-magmatic, I-type differentiates, whereas xenotime is rare or absent. The fractionation of apatite effectively decreases $\mathrm{P}$ and REE contents, and as a result, the amount of apatite originating later from residual melts (Bea et al. 1992). Apatite crystallizes both as an early-magmatic phase and a late-magmatic phase. Early-magmatic apatite is usually trapped in early biotite. In contrast, the late apatite usually forms with late titanite and magnetite - a paragenesis reflecting interaction between $\mathrm{Ca}^{2+}$ released from anorthite and the products of disintegrated titanomagnetite, biotite and earlier apatite (Broska et al. 2007).

\subsection{S-type granites}

In the S-type granites where most of the phosphorus is divided between monazite and apatite, the latter is not so abundant. The lower apatite concentration in S-type granite, especially in their late peraluminous differentiates also reflects the berlinite substitution in feldspars which involves part of the melt P (London et al. 1990; Frýda and Breiter 1995). Increased fluorine activity, and other late corrosive fluids, can leach the P from feldspar (Breiter et al. 1997; Breiter et al. 2002; Broska et al. 2002) especially from P-rich, specialized granites. The secondary apatite may reprecipitate as fine disseminated grains in alkali feldspars, or in tiny veins (Fig. 3A, B). However, abundant late apatite may form in peraluminous S-type melts such as the Suchý and Malá Magura leucogranites. Here, the late apatite did not act as a $\mathrm{P}$ buffer in the strongly peraluminous melts and its content could have built up to $0.6 \% \mathrm{P}_{2} \mathrm{O}_{5}$. The mobility of fluids enriched in $\mathrm{P}$ and high field strength elements (REE, Th, $\mathrm{U}$ ) make the formation of dikes in 
the granite exocontact very probable (Fig. 3C, D). Such veins in the Čučma area (Gemeric unit) have been interpreted as due to leaching of elements from black shales (Rojkovič et al. 1999). We re-interpret these phosphate occurrences as due to granite emplacement and P, REE, Th, U rich fluids release from granites.

Monazite usually occurs in the form of typical prismatic- and tabular crystals of yellow, yellow-green or orange colour. Monazite composition is quite uniform but some trends in composition are seen. The huttonite component in monazite-(Ce) is related to temperature; higher content are typically characterise monazites of higher temperature origin (Broska et al. 2000). In the evolved S-type granites, monazite has an increased cheralite component.

During the evolution of granitic melts, monazite-(Ce) shows varying degrees of abundance. Harker diagrams for the granitoids of the Western Carpathians display an irregular, kinked, LREE distribution - generally with a negative trend (Fig. 6). This LREE irregularity is reflected in monazite contents. With Ce decreasing due to fractionation, monazite contents also decrease. However, at ca. $70 \mathrm{wt} \% \mathrm{SiO}_{2}$, increases in Ce- and monazite contents are again seen (Fig. 6). This can be explained by the presence of the berlinite molecule in feldspars as apatite and monazite contents are controlled by the berlinite substitution. This effect was first explained by London (1992) who experimentally showed that berlinite substitution starts to operate during the increase in melt peraluminosity. When $\mathrm{P}$ is trapped by feldspars, apatite becomes soluble and monazite- $(\mathrm{Ce})$ is not stable - decreasing melt $\mathrm{P}$ in the melt inhibits later the precipitation of accessory monazite.
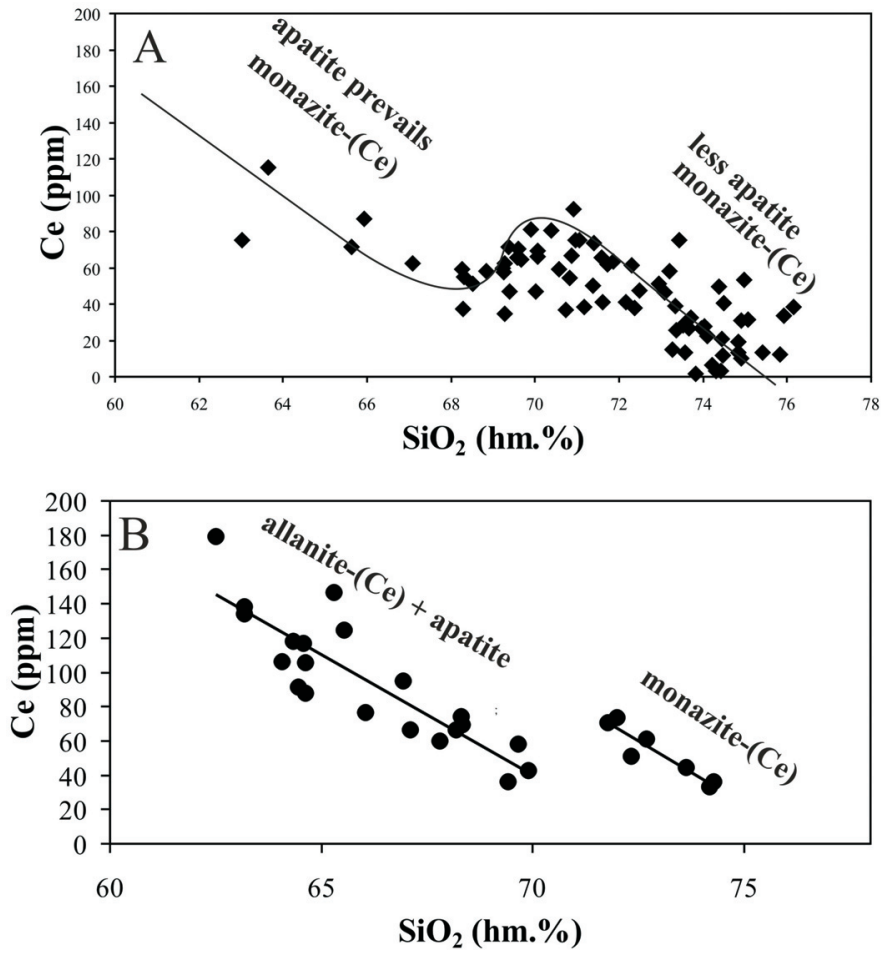

Fig. 6. Irregular distribution of $\mathrm{Ce}$ vs. $\mathrm{SiO}_{2}$ in the S-type granites showing changes of monazite stability during fractionation 
Xenotime- $(\mathrm{Y})$ abundances are the most variable. As there is no significant correlation between $\mathrm{Y}, \mathrm{HREE}$ and xenotime-(Y) abundances, the precipitation of secondary xenotime may be significant. Xenotime is designated as late magmatic on the basis of magmatic structural features and equilibration with monazite.

In some contrast, the F- and Li-rich granites from the Gemeric unit (specialized S-type) may show very different phosphate mineralogy. In P-rich, Li-F granite porphyries, assemblages of rarer phosphates are seen. In albite- and topas-rich rock, where Li-muscovite and zinnwaldite are the only stable micas, the stability of apatite is apparently suppressed and abundant phosphorus, not buffered in the strongly peraluminous Ca-poor melt, enters into other late phosphates. Low $\mathrm{Ca}$ activity, reflected in the absence of plagioclase and biotite, and the excess of $\mathrm{Na}, \mathrm{Mn}$, $\mathrm{Fe}$ and $\mathrm{Sr}$, lead to the formation fluorophosphates, e,g., lacroixite $\left[\mathrm{NaAl}\left(\mathrm{PO}_{4}\right) \mathrm{F}\right]$, arrojadite $\left[\mathrm{KNa}_{4} \mathrm{CaMn}_{4} \mathrm{Fe}_{10} \mathrm{Al}\left(\mathrm{PO}_{4}\right)_{12}(\mathrm{~F}, \mathrm{OH})_{2}\right]$, goyazite $\left[\mathrm{SrAl}_{3}\left(\mathrm{PO}_{4}\right)_{2}(\mathrm{OH})_{5} \cdot\left(\mathrm{H}_{2} \mathrm{O}\right)\right]$ and viitaniemite $\left[\mathrm{Na}(\mathrm{Ca}, \mathrm{Mn}) \mathrm{Al}\left(\mathrm{PO}_{4}\right)(\mathrm{F}, \mathrm{OH})_{3}\right]$. Minor apatite does occur in local Ca-rich domains. Very low REE concentrations decree an almost total lack of monazite and xenotime.

Acknowledgments. The work was financed by projects APVT 13604 and GA 7076. J. Leichmann is thanked for the CL images and I. Dianiška for samples of Dlhá dolina specialized granites. The authors would like to express their gratitude to Michael Williams for the improving of an earlier version of the manuscript.

\section{References}

BEA F., FERSHTATER G., CORRETGÉ L.G., 1992: The geochemistry of phosphorus in granite and the effect of aluminium. Lithos 29, 43-45.

BOWIE S.H.U., HORNE J.E.T., 1953: Cheralite, a new mineral of the monazite group. Mineralogical Magazine 30 , 93-99.

BREITER K., FRÝDA J., LEICHMANN, J., 2002: Phosphorus and rubidium in alkali feldpars: case studies and possible genetic interpretation. In: Breiter K., 2002 (Ed.): Phosphorus- and fluorine-rich fractionated granites. Bulletin of the Czech Geological Survey 77, 93-104.

BREITER K., FRÝDA J., SELTMAN R., THOMAS R., 1997: Mineralogical evidence for two magmatic stages in the evolution of an extremely fractionated P-rich rare-metal granite: the Podlesí stock, Krušné Hory, Czech Republic. Journal of Petrology 38, 1723-1739.

BROSKA I., SIMAN P., 1998: The breakdown of monazite in the West-Carpathian Veporic orthogneisses and Tatric granites. Geologica Carpathica 49, 161-167.

BROSKA I., PETRÍK I., WILLIAMS C.T., 2000: Coexisting monazite and allanite in peraluminious granitoids of the Tribeč Mountains, Western Carpathians. American Mineralogist 85, 22-32.

BROSKA, I., KUBIŠ, M., WILLIAMS, C.T., KONEČNÝ, P. 2002. The composition of rock-forming and accessory minerals from the Gemeric granites (Hnilec area, Gemeric superunit, Western Carpathians). Bulletin of the Czech Geological Survey 7, 147-155.

BROSKA I., WILLIAMS C.T., UHER P., KONEČNÝ P., LEICHMANN J., 2004: The geochemistry of phosphorus in different granite suites of the Western Carpathians, Slovakia: the role of apatite and P-bearing feldspar. Chemical geology 205, 1-15.

BROSKA I., WILliAMS C. T., JANÁK M., NAGY G., 2005: Alteration and breakdown of xenotime-(Y) and monazite-(Ce) in granitic rocks of the Western Carpathians, Slovakia. Lithos 82, 71-83.

BROSKA I., HARLOV D., TROPPER P., SIMAN P., 2007: Formation of magmatic titanite and titanite-ilmenite phase relations during granite alteration in the Tribeč mountains, Western Carpathians, Slovakia. Lithos 95, 58-71.

BURT, D.M., 1989: Compositional and phase relations among rare earth element minerals. In: Geochemistry and mineralogy of rare earth elements, B.R. Lipin \& G.A. McKay (Eds.). Reviews in Mineralogy 21, $298-306$. 
BUDZYŇ B., KONEČNÝ P., MICHALIK M., 2006: Breakdown of primary monazite and formation of secondary monazite in gneiss clasts from Gródek at the Jezioro Roźnowskie lake (Poland). Mineralogia Polonica - Special Papers 28, 33-35.

CATLOS E., GILLEY L.D., HARRISON T.M., 2002: Interpretation of monazite ages obtained via in situ analysis. Chemical Geology 188, 193-215.

CUNEY M., FRIEDRICH M., 1987: Physicochemical and crystal-chemical control on accessory mineral paragenesis in granitoids: Implications for uranium metallogenesis. Bulletin Minèralogie 110, 235-247.

FINGER, F., KRENN. E., 2007: Three metamorphic monazite generations in a high-pressure rock from the Bohemian Massif and the potentially important role of apatite in stimulating polyphase monazite growth along a PT loop. Lithos 95, 103-115.

FRÝDA J., BREITER K., 1995. Alkali feldspars as a main phosphorus reservoir in rare-metal granites: three examples from the Bohemian Massif (Czech Republic). Terra Nova 7, 315-320.

FÖRSTER H.J., 1998a. The chemical composition of REE-Y-Th-U-rich accessory minerals in peraluminous granites of the Erzgebirge-Fichtelgebirge region, Germany. Part I. The monazite-(Ce)-brabantite solid solution series. American Mineralogist 83, 259-272.

FÖRSTER, H.J., 1998b. The chemical composition of REE-Y-Th-U-rich accessory minerals in peraluminous granites of the Erzgebirge-Fichtelgebirge region, Germany, Part II. Xenotime. American Mineralogist 83, $1302-1315$.

GROMET L.P., SILVER L.T., 1983: Rare earth element distributions among minerals in a granodiorite and their petrological implications. Geochimimica Cosmochimica Acta 47, 952-938.

HARLOV D.E., FÖRSTER H.J., 2003: Fluid-induced nucleation of (Y+REE)-phosphate minerals within apatite: Nature and experiments. Part II. Fluorapatite. American Mineralogist 88, 1209-1209.

HARLOV D.E., WIRTH R., FÖRSTER H.J., 2005: An experimental study of dissolution-reprecipitation in fluorapatite: fluid infiltration and formation of monazite. Contributions to Mineralogy and Petrology 150, $268-286$.

HEINRICH W., ANDREHS G., FRANZ G., 1997: Monazite-xenotime miscibility gap thermometer. 1. An empirical calibration. Journal of Metamorphic Geology 15, 3-16.

HUGHES J.M., RAKOVAN J., 2002: The crystal structure of apatite: $\mathrm{Ca}_{5}\left(\mathrm{PO}_{4}\right)_{3}(\mathrm{~F}, \mathrm{OH}, \mathrm{Cl})$. In: Phosphates. Geochemical, Geobiological, and Materials Importance. Kohn M.J., Rakovan J., Hughes J.M.(Eds.): Reviews of Mineralogy and Geochemistry 48, 1-12.

JANOTS E., BRUNET F., GOFFÉ B., POINSSOT C., BYRCHARD M., CEMIC L., 2007: Thermochemistry of monazite-(La) and dissakisite-(La): implications for monazite and allanite stability in metapelites. Contributions to Mineralogy and Petrology 154, 1-14.

KRENN E., FINGER F., 2007: Formation of monazite and rhabdophane at the expense of aalanite during Alpine low temperature retrogression of metapelitic basement rocks from Crete, Greece. Microprobe data and geochronological implications. Lithos 95, 130-147

KUCHA H., 1980: Continuity in the monazite-huttonite series. Mineralogical Magazine 43, 387-393.

LINTHOUT K., 2007: Tripartite division of the system $2 \mathrm{REEPO}_{4}-\mathrm{CaTh}\left(\mathrm{PO}_{4}\right)_{2}-2 \mathrm{ThSiO}_{4}$, discreditation of brabantite, and recognition of cheralite as the name for members dominated by $\mathrm{CaTh}\left(\mathrm{PO}_{4}\right)_{2}$. Canadian Mineralogist 45, 503-508.

LONDON D., ČERNÝ P., LOOMIS J.L., PAN J.J., 1990. Phosphorus in alkali feldspars of rare-element granitic pegmatites. Canadian Mineralogist 28, 771-786.

LONDON D., 1992: Phosphorus in S-type magmas: the $\mathrm{P}_{2} \mathrm{O}_{5}$ content of feldspars from peraluminious granites, pegmatites and rhyolites. American Mineralogist 77, 126-145.

LONDON D., 1998: Phosphorus-rich peraluminious granites. Acta Universitatis Carolinae-Geologica 42, 64-68.

MAJKA J., BUDZYŇ B., 2006: Monazite breakdown in metapelites from Wedel Jarlsberg Land, Svalbard - preliminary report. Mineralogia Polonica 37, 61-68.

MICHALIK M., SKUBLICKI L., 1999: Phosphate accessory minerals in High Tatra granitoids. Geologica Carpathica 50, Spec. Issue, 123-125.

MICHALIK M., POPCZYK R., KUSIAK M., PASZKOWSKI M., 2000: Xenotime zircon intergrowths in the Western Tatra leucogranites. Mineralogical Society of Poland - Special Papers 17, 249-251.

NASH W.P., 1972: Apatite chemistry and phosphorus fugacity in a differentiated igneous intrusion. American Mineralogist 57, 877-886. 
NI Y., HUGHES J.M., MARIANO, A.M., 1995: Crystal chemistry of the monazite and xenotime structures. American Mineralogist 80, 21-26.

ONDREJKA M., UHER P., PRS̆EK J., OZDÍN D., 2007: Arsean monazite-(Ce) and xenotime-(Y), REE arsenates and carbonates from the Tisovec-Rejkovo rhyolite, Western Carpathians, Slovakia: Composition and substitution in the (REE, Y) $\mathrm{XO}_{4}$ system (X = P, As, Si, Nb, S). Lithos 95, 116-129.

PAN Y., 1997: Zircon- and monazite forming metamorphic reactions at Manitouwadge, Ontario. Canadian Mineralogist 35, 105-118.

PAN, Y., FLEET M.E., 2002: Compositions of the apatite-group minerals: substitution mechanism and controlling factors. In: Phosphates. Geochemical, Geobiological, and Materials Importance. Kohn M.J., Rakovan J., Hughes J.M. (Eds.). Reviews of Mineralogy and Geochemistry 48, 13-50.

PETRÍK I., KONEČNÝ P., KOVÁČIK, M., HOLICKÝ, I. 2006: Electron microprobe dating of monazite from the Nizke Tatry Mountains orthogneisses (Western Carpathians, Slovakia). Geologica Carpathica 57, $227-242$.

PLAŠIENKA, D., GRECULA, P., PUTIŠ, M., HOVORKA, D. \& KOVÁČ, M., 1997. Evolution and structure of the Western Carpathians: an overview. In: Geological Evolution of the Western Carpathians (eds. P. Grecula, D. Hovorka \& M. Putiš), Mineralia Slovaca, Monograph, 1-24.

PYLE J.M., SPEAR F.S., RUDNICK R.L. \& MCDONOUGH W.F., 2001: Monazite-xenotime and monazite-garnet equilibrium in a prograde pelite sequence. Journal of Petrology 42, 2083-2107.

ROSE D., 1980: Brabantite, CaTh[$\left[\mathrm{PO}_{4}\right]_{2}$, a new mineral of the monazite group. Neues Jahrbuch für Mineralogy, Monatshefte 247-257.

ROJKOVIČ I., KONEČNÝ P., NOVOTNÝ L., PUŠKELOVÁ L., STREŠKO V., 1999: Quartz-apatite-REE vein mineralization in early paleozoic rocks of the Gemeric superunit, Slovakia. Geologica Carpathica 50, $215-227$.

SPEAR F., PYLE J.M., 2002: Apatite, monazite and xenotime in metamorphic rocks. In: Phosphates. Geochemical, Geobiological, and Materials Importance. Kohn M.J., Rakovan J., Hughes J.M.(Eds.): Reviews in Mineralogy and Geochemistry 48, 293-335.

UHER P., MALACHOVSKÝ P., DIANIŠKA I., KUBIŠ M., 2001: Rare-element Nb-Ta-W mineralization of the tin-bearing Spiš-Gemer granites, Eastern Slovakia. GeoLines 13, 119-120.

WATSON E.B., CAPOBIANCO C.J., 1981: Phosphorus and rare earth elements in felsic magmas. An assesment of the role of apatite. Geochimica Cosmochimica Acta 45, 2349-2358.

WATSON E.B., HARRISON, T.M. 1984: What can accessory minerals tell us about felsic magma evolution? A framework for experimental study. Proceedings $27^{\text {th }}$ International Geological Congres 11, 503-520. 
